\title{
SLC27 family of fatty acid transporters (version 2019.4) in the IUPHAR/BPS Guide to Pharmacology Database
}

\author{
Andreas Stahl 1 \\ 1. UC Berkeley, USA
}

\begin{abstract}
Fatty acid transporter proteins (FATPs) are a family (SLC27) of six transporters (FATP1-6). They have at least one, and possibly six $[4,11]$, transmembrane segments, and are predicted on the basis of structural similarities to form dimers. SLC27 members have several structural domains: integral membrane associated domain, peripheral membrane associated domain, FATP signature, intracellular AMP binding motif, dimerization domain, lipocalin motif, and an ER localization domain (identified in FATP4 only) [2, 8, 9]. These transporters are unusual in that they appear to express intrinsic very long-chain acyl-CoA synthetase (EC 6.2.1.- , EC 6.2.1.7) enzyme activity. Within the cell, these transporters may associate with plasma and peroxisomal membranes. FATP1-4 and -6 transport long- and very long-chain fatty acids, while FATP5 transports long-chain fatty acids as well as bile acids $[7,11]$.
\end{abstract}

\section{Contents}

This is a citation summary for SLC27 family of fatty acid transporters in the Guide to Pharmacology database (GtoPdb). It exists purely as an adjunct to the database to facilitate the recognition of citations to and from the database by citation analyzers. Readers will almost certainly want to visit the relevant sections of the database which are given here under database links.

GtoPdb is an expert-driven guide to pharmacological targets and the substances that act on them. GtoPdb is a reference work which is most usefully represented as an on-line database. As in any publication this work should be appropriately cited, and the papers it cites should also be recognized. This document provides a citation for the relevant parts of the database, and also provides a reference list for the research cited by those parts.

Please note that the database version for the citations given in GtoPdb are to the most recent preceding version in which the family or its subfamilies and targets were substantially changed. The links below are to the current version. If you need to consult the cited version, rather than the most recent version, please contact the GtoPdb curators.

\section{Database links}

SLC27 family of fatty acid transporters

http://www.guidetopharmacology.org/GRAC/FamilyDisplayForward?familyld=214

Transporters

FATP1(Fatty acid transport protein 1) 
http://www.guidetopharmacology.org/GRAC/ObjectDisplayForward?objectld=1108

FATP2(Fatty acid transport protein 2)

http://www.guidetopharmacology.org/GRAC/ObjectDisplayForward?objectld=1109

FATP3(Fatty acid transport protein 3)

http://www.guidetopharmacology.org/GRAC/ObjectDisplayForward?objectld=1110

FATP4(Fatty acid transport protein 4)

http://www.guidetopharmacology.org/GRAC/ObjectDisplayForward?objectld=1111

FATP5(Fatty acid transport protein 5)

http://www.guidetopharmacology.org/GRAC/ObjectDisplayForward?objectld=1112

FATP6(Fatty acid transport protein 6)

http://www.guidetopharmacology.org/GRAC/ObjectDisplayForward?objectld=1113

\section{References}

1. Blackburn C, Guan B, Brown J, Cullis C, Condon SM, Jenkins TJ, Peluso S, Ye Y, Gimeno RE and Punreddy $S$ et al.. (2006) Identification and characterization of 4-aryl-3,4-dihydropyrimidin-2(1H)-ones as inhibitors of the fatty acid transporter FATP4. Bioorg. Med. Chem. Lett. 16: 3504-9 [PMID:16644217]

2. Faergeman NJ, DiRusso CC, Elberger A, Knudsen J and Black PN. (1997) Disruption of the Saccharomyces cerevisiae homologue to the murine fatty acid transport protein impairs uptake and growth on long-chain fatty acids. J. Biol. Chem. 272: 8531-8 [PMID:9079682]

3. Gimeno RE, Ortegon AM, Patel S, Punreddy S, Ge P, Sun Y, Lodish HF and Stahl A. (2003) Characterization of a heart-specific fatty acid transport protein. J. Biol. Chem. 278: 16039-44 [PMID:12556534]

4. Lewis SE, Listenberger LL, Ory DS and Schaffer JE. (2001) Membrane topology of the murine fatty acid transport protein 1. J. Biol. Chem. 276: 37042-50 [PMID:11470793]

5. Li H, Black PN, Chokshi A, Sandoval-Alvarez A, Vatsyayan R, Sealls W and DiRusso CC. (2008) Highthroughput screening for fatty acid uptake inhibitors in humanized yeast identifies atypical antipsychotic drugs that cause dyslipidemias. J. Lipid Res. 49: 230-44 [PMID:17928635]

6. Matsufuji T, Ikeda M, Naito A, Hirouchi M, Kanda S, Izumi M, Harada J and Shinozuka T. (2013) Arylpiperazines as fatty acid transport protein 1 (FATP1) inhibitors with improved potency and pharmacokinetic properties. Bioorg. Med. Chem. Lett. 23: 2560-5 [PMID:23528296]

7. Mihalik SJ, Steinberg SJ, Pei Z, Park J, Kim DG, Heinzer AK, Dacremont G, Wanders RJ, Cuebas DA and Smith KD et al.. (2002) Participation of two members of the very long-chain acyl-CoA synthetase family in bile acid synthesis and recycling. J. Biol. Chem. 277: 24771-9 [PMID:11980911]

8. Milger K, Herrmann T, Becker C, Gotthardt D, Zickwolf J, Ehehalt R, Watkins PA, Stremmel W and Füllekrug J. (2006) Cellular uptake of fatty acids driven by the ER-localized acyl-CoA synthetase FATP4. J. Cell. Sci. 119: 4678-88 [PMID:17062637]

9. Ordovás L, Roy R, Zaragoza P and Rodellar C. (2006) Structural and functional characterization of the bovine solute carrier family 27 member 1 (SLC27A1) gene. Cytogenet. Genome Res. 115: 115-22 [PMID:17065791]

10. Sandoval A, Chokshi A, Jesch ED, Black PN and Dirusso CC. (2010) Identification and characterization of small compound inhibitors of human FATP2. Biochem. Pharmacol. 79: 990-9 [PMID:19913517]

11. Schaffer JE and Lodish HF. (1994) Expression cloning and characterization of a novel adipocyte long chain fatty acid transport protein. Cell 79: 427-36 [PMID:7954810]

12. Stahl A, Hirsch DJ, Gimeno RE, Punreddy S, Ge P, Watson N, Patel S, Kotler M, Raimondi A and Tartaglia LA et al.. (1999) Identification of the major intestinal fatty acid transport protein Mol. Cell 4: 299308 [PMID:10518211]

13. Zhou W, Madrid P, Fluitt A, Stahl A and Xie XS. (2010) Development and validation of a high-throughput screening assay for human long-chain fatty acid transport proteins 4 and 5. J Biomol Screen 15: 488-97 [PMID:20448275] 
